African Crop Science Journal by African Crop Science Society is licensed under a Creative Commons Attribution 3.0 Uganda License. Based on a work at www.ajol.info/ and www.bioline.org.br/cs DOI: https://dx.doi.org/10.4314/acsj.v28i1.1S

\title{
EFFECTIVE ISOLATION DISTANCE FOR PREVENTION OF CASSAVA VIRUS INFECTIONS IN UGANDA
}

\author{
F. KASULE, P. WASSWA, S.B. MUKASA, A. OKIROR and A.W. MWANG'OMBE ${ }^{1}$ \\ College of Agricultural and Environmental Sciences, Department of Agricultural Production, \\ Makerere University, P. O. Box 7062, Kampala, Uganda \\ ${ }^{1}$ Department of Plant Science and Crop Protection, University of Nairobi, P. O. Box 30197-00100, \\ Nairobi, Kenya \\ Corresponding author: kfay337@gmail.com
}

\begin{abstract}
Cassava brown streak disease (CBSD) and cassava mosaic disease (CMD) are the major viral diseases of cassava in Uganda. Although isolation distance of " $50 \mathrm{~m}$ " has been recommended by MAAIF in Uganda for prevention of virus infections in crops, the minimum isolation distance has not been verified for effectiveness in cassava. This study assessed the effective isolation distance for management of viral diseases in cassava. Virus-clean cassava cultivars (NASE 03, NASE 14 and NAROCASS 1) from farmers' fields were used as field sourced (FS) planting materials. Tissue culture (TC) material of the same cultivars were sourced from the National Crops Resources Research Institute and Makerere University Agricultural Research Institute tissue culture laboratories. Both FS and TC materials were tested at isolation distances of $50,100,150$ and $250 \mathrm{~m}$ for virus prevention. The experiment was laid out in a randomised complete block design and was run for 12 months after planting (MAP). Mean CBSD/CMD prevalence significantly varied $(\mathrm{P}<0.05)$ among isolation distances in both FS and TC plants, and the $250 \mathrm{~m}$ isolation distance was the most effective in reducing disease prevalence. Across cultivars and planting material category at $12 \mathrm{MAP}$, the $50 \mathrm{~m}$ isolation distance had the highest foliar incidence for CBSD $(29.2 \%)$ and CMD (16.1\%); while severity for CBSD was 1.4 and 1.2 for CMD. At $250 \mathrm{~m}$, all FS and TC plants had CBSD/CMD severity of 1.0 and $0 \%$ incidence. These results show that $250 \mathrm{~m}$ isolation distance can provide an option to disseminate popular, but CBSD/ CMD susceptible cassava cultivars thereby manage CBSD/CMD.
\end{abstract}

Key Words: Cassava brown streak disease, cassava mosaic disease

\section{RÉSUMÉ}

La maladie des stries brunes du manioc (CBSD) et la maladie de la mosaïque du manioc (CMD) sont les principales maladies virales du manioc en Ouganda. Bien qu'une distance d'isolement de « $\$ 0 \mathrm{~m} »$ ait été recommandée par le MAAIF en Ouganda pour la prévention des infections virales dans les cultures, l'efficacité minimale de la distance d'isolement n'a pas été vérifiée dans le manioc. Cette étude a évalué la distance d'isolement efficace pour la gestion des maladies virales dans le manioc. 
Des cultivars de manioc sans virus (NASE 03, NASE 14 et NAROCASS 1) provenant des champs des agriculteurs ont été utilisés comme le source de matériel de plantation (FS). Le matériel de culture tissulaire (TC) des mêmes cultivars provenait des laboratoires National Crops Resources Research Institute and Makerere University Agricultural Research Institute tissue culture. Les matériaux FS et TC ont été testés à des distances d'isolement de $50,100,150$ et $250 \mathrm{~m}$ pour la prévention des virus. L'expérience a été présentée dans un bloc complet randomisé et a été réalisée pendant 12 mois après la plantation (MAP). La prévalence moyenne de CBSD / CMD variait significativement $(\mathrm{P}<0,05)$ entre les distances d'isolement dans les plantes FS et TC, et la distance d'isolement de $250 \mathrm{~m}$ était la plus efficace pour réduire la prévalence de la maladie. À travers les cultivars et la catégorie de matériel de plantation à $12 \mathrm{MAP}$, la distance d'isolement de $50 \mathrm{~m}$ avait l'incidence foliaire la plus élevée pour le CBSD (29,2\%) et le CMD (16,1\%); tandis que la gravité pour CBSD était de 1,4 et 1,2 pour CMD. À 250 $\mathrm{m}$, toutes les plantes FS et TC avaient une gravité CBSD / CMD de 1,0 et une incidence de $0 \%$. Ces résultats montrent qu'une distance d'isolement de $250 \mathrm{~m}$ peut fournir une option pour disséminer des cultivars de manioc sensibles au CBSD / CMD, ce qui permet de gérer le CBSD / CMD.

Mots Clés: Maladie des stries brunes du manioc, maladie de la mosaïque du manioc

\section{INTRODUCTION}

Cassava (Manihot esculenta Crantz) is a staple food crop, cultivated in many parts of Africa. In Uganda cassava is grown in all parts of the country, with eastern and northern regions being the major producer (FAOSTAT, 2017; UBOS, 2017). However, cassava production worldwide is constrained by a number of biotic factors. Of the biotic factors, cassava brown streak disease (CBSD) caused by cassava brown streak viruses and cassava mosaic disease (CMD) caused by different species of cassava mosaic geminiviruses (CMGs) are the major viral diseases leading to severe yield losses of up to $100 \%$ (Legg et al., 2011; Legg et al., 2014). CBSVs and CMGs are transmitted by whitefly, Bemisia tabaci Gennadius, and can also be spread in cuttings, which is exacerbated by the virtue that cassava is predominantly vegetatively propagated (Legg et al., 2015).

CBSD and CMD are prevalent in all agroecological zones in Uganda and most cassava fields usually have both diseases on the same cassava plants at the same time (Kawuki et al., 2017). Therefore, management strategies require that both diseases are simultaneously controlled. CBSD and CMD prevention is done using several ways; but breeding for resistance is the most sustainable strategy, especially for the resource poor farmers. However, cassava varieties such as NASE 14, bred for resistance to CMV, succumb to CBSV (Kawuki et al., 2017; Mukiibi et al., 2019). Genetic engineering has been tried to introduce CBSD resistance into CMD resistant varieties, such as TME 204; but after successful transformation, such varieties lost resistance to CMD (Beyene et al., 2016; Beyene et al., 2017). Besides, most times, resistant varieties are not the most preferred by farmers as they are deficient in some farmer preferred attributes (Nakabonge et al., 2017). Therefore, cassava farmers in Uganda are largely left with only the option of using clean planting material of their preferred cultivars, when establishing new fields. Such clean planting materials are obtained from tissue culture laboratories and distributed to seed multipliers in 'isolated' fields (Legg et al., 2011; Nakabonge et al., 2017). The seed multipliers can multiply seed for several generations from the same tissue culture stock material, and such material ideally becomes field sourced material after exposure for several generations.

Several isolation distances have been recommended and adopted by seed multipliers and inspectors for the multiplication of clean 
cassava planting materials. Isolation distance of " $50 \mathrm{~m}$ " has been recommended by MAAIF in Uganda (MAAIF, 2010). According to Delimini (2012), cassava fields having breeder seed, should at least have 200 meters separating breeder seed from neighbouring cassava fields, and 100 meters separating basic seed from other fields. However, there has been no research done to empirically establish these isolation distances and compare CBSV and CMV infection rates between tissue culture derived and field sourced cassava planting materials. While shorter distances may not be effective, longer isolation distance would pose a constraint to small-scale and land limited farmers during certified clean seed multiplication, thus a need for an optimum isolation distance. This study was, therefore, conducted to establish the effective isolation distance for simultaneous prevention of CBSV and CMV infections in tissue culture derived and field sourced planting materials.

\section{MATERIALS AND METHODS}

Study site. The study was carried out in a field at the Makerere University Agriculture Research Institute, Kabanyolo (MUARIK) in Uganda, in 2018/2019. MUARIK is located at a latitude of $0^{\circ} 282 \mathrm{~N}$ of the equator, longitude of $32^{\circ} 372 \mathrm{E}$ and at 1200 meters above sea level. MUARIK is located near to Namulonge (longitude of $32^{\circ} 372 \mathrm{E}, 0^{\circ} 32^{\prime}$ ); a known hotspot for whiteflies and cassava viral diseases (Abaca et al., 2012; Kaweesi et al., 2014); hence buildup of inoculum and its spread was presumed.

Plant materials. A total of 288 plants of three cassava cultivars (NASE 03, NASE 14 and NAROCASS 1) were used in this study. NASE 03 and NASE 14 are the most preferred by farmers, at least in eastern Uganda; yet susceptible to CBSV and CMV (unpublished). NAROCASS 1 was included as a check because of its high levels of resistance to both viruses (Mukiibi et al., 2019).
For field sourced materials, cultivars were sourced from farmers' fields in eastern Uganda (Bukedea and Kumi districts). Plants were checked for healthy status by extracting total nucleic acids from the leaves using a modified cetyltrimethyl ammonium bromide (CTAB) method (Maruthi et al., 2002). The extracted nucleic acids were run in PCR/RT-PCR reaction protocols using CMV and CBSV degenerate primers.

For the tissue culture-derived materials, similar cultivars (NASE 03, NASE 14 and NAROCASS 1 were sourced from National Crops Resources Research Institute (NaCRRI) and MUARIK tissue culture laboratories and included in the field experiment.

Virus inoculation and management. Elephant grass (Pennisetum purpureum) was planted around the whole perimeter and longitudinally between different treatment blocks, 4 months before planting the cassava experimental treatment blocks. This was done to allow elephant grass to establish as a barrier crop so as to block whiteflies from transmitting CBSV and CMV from other unintended sources, and to separate the different treatment blocks (Maruthi et al., 2017). The infected spreader rows of highly CBSV-susceptible TME 204 and CMV-susceptible Bao cassava cultivars (Abaca et al., 2012; Kawuki et al., 2016), were planted at one extreme end of the experimental block at spacing of $1 \mathrm{~m} \mathrm{x} 1 \mathrm{~m}$, two months before planting the cassava treatment blocks.

Experimental design and management. For the treatment blocks, the experiment was laid out in a randomised complete block design. The isolation distances used in this study were 50, 100, 150 and $250 \mathrm{~m}$. For each distance, two planting material categories, field sourced (FS) and tissue culture-derived (TC), were used. Two blocks were used for each source of planting materials per isolation distance; and each block had three cassava cultivars (NASE 03, NASE 14 and NAROCASS 1). Six 
replications/plants of each of the cultivars were planted at spacing of $1 \mathrm{~m} \mathrm{x} 1 \mathrm{~m}$.

The field was left to natural whitefly infestation, similar to farmers practice; without spraying throughout the study period. Experimental field was kept weed free by manual weeding and no fertiliser was applied. Occasional irrigation of the infectors and experimental blocks was done during excessive dry conditions, especially when plants were still young. Irrigation was done using a watering can in the evenings after every three days, for up to two weeks, giving three litres of tap water per plant per irrigation.

Data collection and analysis. The CBSD and CMD incidence and severity were assessed at 4, 8 and 12 months after planting (MAP). For CBSD severity, the assessment was done using foliar and stem symptoms, and was based on a scale of 1 - 5 (Gondwe et al., 2003). Where $1=$ no apparent symptoms; $2=$ slight foliar feathery chlorosis and no stem lesions; 3 = pronounced foliar feathery chlorosis, mild stem lesions, and no dieback; $4=$ severe foliar feathery chlorosis, severe stem lesions, and no dieback; and $5=$ defoliation, severe stem lesions and dieback.

CMD severity was assessed using a $1-5$ severity scale (IITA, 1990). Where $1=$ no symptoms observed (shoot healthy); $2=$ mild chlorotic pattern on most leaves, mild distortions at the bases of most leaves, with the remaining parts of the leaves and leaûets appearing green and healthy; $3=$ a pronounced mosaic pattern on most leaves, with narrowing and distortion of the lower one-third of most leaves; 4 = severe mosaic distortion of twothirds of most leaves, with general reduction in leaf size and some stunting of shoots; and 5 = very severe mosaic symptoms on all leaves, with distortion, twisting, and severe reduction in leaf size in most leaves, accompanied by severe stunting of plants. The CBSD and CMD incidences data were obtained from the number of plants showing foliar disease symptoms, expressed as a percentage of the total number of plants assessed.
For CBSD root severity at harvest (12 MAP), plants in each plot were uprooted and all roots cut transversally and assessed for CBSD root severity, using the 1-5 scale. Where, $1=$ no necrosis, $2=$ mild necrotic lesions $(1-10 \%), 3=$ pronounced necrotic lesion $(11-25 \%), 4=$ severe necrotic lesion (26-50\%) with mild root constriction and $5=$ very severe necrotic lesion $(>50 \%)$ with severe root constriction (Kaweesi et al., 2014). Disease root incidence of CBSD in harvested roots was quantified as a ratio of the number of roots showing roots symptoms to the total number of roots harvested per plant per genotype (Kaweesi et al., 2014).

Data on disease severity and incidence for cultivars, planting materials and isolation distance were subjected to analysis of variance using GenStat $14^{\text {th }}$ edition (Payne et al., 2011). Comparisons of means were made using Fisher's protected LSD at $\mathrm{P}<0.05$.

\section{RESULTS AND DISCUSSION}

This study assessed a number of 288 cassava plants; 144 plants from TC material and 144 plants from FS material of NASE 03, NASE 14 and NAROCASS 1 cassava cultivars. The aim was to assess for CBSV and CMV infection at varying isolation distances of 50, 100,150 and $250 \mathrm{~m}$ in cassava plants from TC and FS material. The study was carried out at the Makerere University Agricultural Research Institute, Kabanyolo (MUARIK), a known hotspot for whitefly population and viral cassava diseases hence buildup of inoculum and its spread was assured (Abaca et al., 2012; Kaweesi et al., 2014).

Results indicated that foliar CBSD and CMD incidences (Tables 1 and 2) and severity (Tables 3 and 4) varied significantly among plants from both tissue-culture derived and field sourced cassava planting materials. Similarly, CBSD root incidence and severity also varied significantly among plants from both TC and FS material (Table 5). These results indicate a differential response of the different cassava planting material category 
TABLE 1. Cassava brown streak disease foliar incidence (\%) for tissue culture and field sourced planting materials per isolation distance at different months after planting at the Makerere University Agriculture Research Institute, Kabanyolo (MUARIK) in Uganda

\begin{tabular}{|c|c|c|c|c|c|c|c|c|c|c|c|c|}
\hline \multirow[t]{3}{*}{ Planting materials } & \multicolumn{12}{|c|}{ Isolation distance (m) } \\
\hline & \multicolumn{3}{|c|}{50} & \multicolumn{3}{|c|}{100} & \multicolumn{3}{|c|}{150} & \multicolumn{3}{|c|}{250} \\
\hline & $4 \mathrm{MAP}$ & $8 \mathrm{MAP}$ & $12 \mathrm{MAP}$ & $4 \mathrm{MAP}$ & $8 \mathrm{MAP}$ & $12 \mathrm{MAP}$ & 4 MAP & 8 MAP & 12 MAP & 4 MAP & $8 \mathrm{MAP}$ & $12 \mathrm{MAP}$ \\
\hline NAROCASS 1 FS & 0 & 0 & 8.3 & 0 & 0 & 0 & 0 & 0 & 0 & 0 & 0 & 0 \\
\hline NAROCASS 1 TC & 0 & 0 & 0 & 0 & 0 & 0 & 0 & 0 & 0 & 0 & 0 & 0 \\
\hline NASE03 FS & 33.33 & 58.33 & 75 & 25 & 41.67 & 58.3 & 0 & 0 & 16.67 & 0 & 0 & 0 \\
\hline NASE03 TC & 25 & 41.67 & 58.3 & 8.33 & 25 & 41.7 & 0 & 0 & 8.3 & 0 & 0 & 0 \\
\hline NASE $14 \mathrm{FS}$ & 0 & 16.67 & 25 & 0 & 0 & 8.3 & 0 & 0 & 0 & 0 & 0 & 0 \\
\hline NASE 14 TC & 0 & 0 & 8.3 & 0 & 0 & 0 & 0 & 0 & 0 & 0 & 0 & 0 \\
\hline Mean & 9.7 & 19.5 & 29.2 & 5.6 & 11.1 & 18.1 & 0 & 0 & 4.2 & 0 & 0 & 0 \\
\hline $\operatorname{LSD}(0.05)$ & 4.37 & 4.98 & 7.46 & 4.37 & 4.98 & 7.46 & 4.37 & 4.98 & 7.46 & 4.37 & 4.98 & 7.46 \\
\hline $\mathrm{CV}(\%)$ & 110.7 & 63.0 & 56.2 & 110.7 & 63.0 & 56.2 & 110.7 & 63.0 & 56.2 & 110.7 & 63.0 & 56.2 \\
\hline \multicolumn{13}{|c|}{$\begin{array}{l}\mathrm{LSD}=\text { the least significant difference at } \mathrm{P}=0.05, \mathrm{CV}=\text { the coefficient of variation, } \mathrm{MAP}=\text { months after planting, } \mathrm{TC}=\text { tissue culture-derived material, } \mathrm{FS} \\
\text { field-sourced panting material }\end{array}$} \\
\hline
\end{tabular}


TABLE 2. Cassava mosaic disease foliar incidence (\%) for tissue culture and field sourced planting materials per isolation distance at different months after planting at the Makerere University Agriculture Research Institute, Kabanyolo (MUARIK) in Uganda

\begin{tabular}{|c|c|c|c|c|c|c|c|c|c|c|c|c|}
\hline \multirow[t]{3}{*}{ Planting materials } & \multicolumn{12}{|c|}{ Isolation distance (m) } \\
\hline & \multicolumn{3}{|c|}{50} & \multicolumn{3}{|c|}{100} & \multicolumn{3}{|c|}{150} & \multicolumn{3}{|c|}{250} \\
\hline & 4 MAP & 8 MAP & 12 MAP & $4 \mathrm{MAP}$ & 8 MAP & 12 MAP & $4 \mathrm{MAP}$ & 8 MAP & $12 \mathrm{MAP}$ & 4 MAP & 8 MAP & 12 MAP \\
\hline NAROCASS 1 FS & 0 & 0 & 0 & 0 & 0 & 0 & 0 & 0 & 0 & 0 & 0 & 0 \\
\hline NAROCASS 1 TC & 0 & 0 & 0 & 0 & 0 & 0 & 0 & 0 & 0 & 0 & 0 & 0 \\
\hline NASE03 FS & 25 & 41.67 & 58.33 & 16.67 & 33.33 & 41.67 & 0 & 8.33 & 25 & 0 & 0 & 0 \\
\hline NASE 03 TC & 16.67 & 33.33 & 50 & 0 & 16.67 & 33.33 & 0 & 0 & 16.67 & 0 & 0 & 0 \\
\hline NASE 14FS & 0 & 0 & 0 & 0 & 0 & 0 & 0 & 0 & 0 & 0 & 0 & 0 \\
\hline NASE 14 TC & 0 & 0 & 0 & 0 & 0 & 0 & 0 & 0 & 0 & 0 & 0 & 0 \\
\hline Mean & 7.0 & 12.5 & 18.1 & 2.8 & 8.3 & 12.5 & 0 & 1.4 & 7.0 & 0 & 0 & 0 \\
\hline $\operatorname{LSD}(0.05)$ & 2.49 & 3.44 & 4.12 & 2.49 & 3.44 & 4.12 & 2.49 & 3.44 & 4.12 & 2.49 & 3.44 & 4.12 \\
\hline $\mathrm{CV}(\%)$ & 99.0 & 59.9 & 42.5 & 99.0 & 59.9 & 42.5 & 99.0 & 59.9 & 42.5 & 99.0 & 59.9 & 42.5 \\
\hline
\end{tabular}

$\mathrm{LSD}=$ the least significant difference at $\mathrm{P}=0.05, \mathrm{CV}=$ the coefficient of variation, $\mathrm{MAP}=$ months after planting, $\mathrm{TC}=$ tissue culture-derived material, $\mathrm{FS}=$ field-sourced panting material 
TABLE 3. Cassava brown streak disease foliar severity for tissue culture and sourced field planting materials per isolation distance at different months after planting at the Makerere University Agriculture Research Institute, Kabanyolo (MUARIK) in Uganda

\begin{tabular}{|c|c|c|c|c|c|c|c|c|c|c|c|c|}
\hline \multirow[t]{3}{*}{ Planting materials } & \multicolumn{12}{|c|}{ Isolation distance $(\mathrm{m})$} \\
\hline & \multicolumn{3}{|c|}{50} & \multicolumn{3}{|c|}{100} & \multicolumn{3}{|c|}{150} & \multicolumn{3}{|c|}{250} \\
\hline & 4 MAP & 8 MAP & 12 MAP & 4 MAP & 8 MAP & 12 MAP & 4 MAP & 8 MAP & 12 MAP & 4 MAP & $8 \mathrm{MAP}$ & 12 MAP \\
\hline NAROCASS 1 FS & 1.0 & 1.0 & 1.083 & 1.0 & 1.0 & 1.0 & 1.0 & 1.0 & 1.0 & 1.0 & 1.0 & 1.0 \\
\hline NAROCASS 1 TC & 1.0 & 1.0 & 1.0 & 1.0 & 1.0 & 1.0 & 1.0 & 1.0 & 1.0 & 1.0 & 1.0 & 1.0 \\
\hline NASE 03 FS & 1.33 & 1.83 & 2.25 & 1.25 & 1.5 & 1.83 & 1.0 & 1.0 & 1.17 & 1.0 & 1.0 & 1.0 \\
\hline NASE 03 TC & 1.25 & 1.5 & 1.75 & 1.08 & 1.25 & 1.5 & 1.0 & 1.0 & 1.08 & 1.0 & 1.0 & 1.0 \\
\hline NASE 14FS & 1.0 & 1.17 & 1.25 & 1.0 & 1.0 & 1.08 & 1.0 & 1.0 & 1.0 & 1.0 & 1.0 & 1.0 \\
\hline NASE 14 TC & 1.0 & 1.0 & 1.17 & 1.0 & 1.0 & 1.0 & 1.0 & 1.0 & 1.0 & 1.0 & 1.0 & 1.0 \\
\hline Mean & 1.1 & 1.3 & 1.4 & 1.1 & 1.1 & 1.2 & 1.0 & 1.0 & 1.0 & 1.0 & 1.0 & 1.0 \\
\hline $\operatorname{LSD}(0.05)$ & 0.07 & 0.12 & 0.15 & 0.07 & 0.12 & 0.15 & 0.07 & 0.12 & 0.15 & 0.07 & 0.12 & 0.15 \\
\hline $\mathrm{CV}(\%)$ & 16.9 & 26.2 & 32.1 & 16.9 & 26.2 & 32.1 & 16.9 & 26.2 & 32.1 & 16.9 & 26.2 & 32.1 \\
\hline
\end{tabular}


TABLE 4. Cassava mosaic disease foliar severity for tissue culture and field sourced planting materials per isolation distance at different months after planting at the Makerere University Agriculture Research Institute, Kabanyolo (MUARIK) in Uganda

\begin{tabular}{|c|c|c|c|c|c|c|c|c|c|c|c|c|}
\hline \multirow[t]{3}{*}{ Planting materials } & \multicolumn{12}{|c|}{ Isolation distance (m) } \\
\hline & \multicolumn{3}{|c|}{50} & \multicolumn{3}{|c|}{100} & \multicolumn{3}{|c|}{150} & \multicolumn{3}{|c|}{250} \\
\hline & 4 MAP & 8 MAP & 12 MAP & 4 MAP & $8 \mathrm{MAP}$ & 12 MAP & 4 MAP & $8 \mathrm{MAP}$ & 12 MAP & 4 MAP & 8 MAP & 12 MAP \\
\hline NAROCASS 1 FS & 1.0 & 1.0 & 1.0 & 1.0 & 1.0 & 1.0 & 1.0 & 1.0 & 1.0 & 1.0 & 1.0 & 1.0 \\
\hline NAROCASS 1 TC & 1.0 & 1.0 & 1.0 & 1.0 & 1.0 & 1.0 & 1.0 & 1.0 & 1.0 & 1.0 & 1.0 & 1.0 \\
\hline NASE 03 FS & 1.25 & 1.42 & 1.83 & 1.17 & 1.33 & 1.5 & 1.0 & 1.08 & 1.25 & 1.0 & 1.0 & 1.0 \\
\hline NASE 03 TC & 1.17 & 1.33 & 1.58 & 1.0 & 1.17 & 1.33 & 1.0 & 1.0 & 1.17 & 1.0 & 1.0 & 1.0 \\
\hline NASE 14 FS & 1.0 & 1.0 & 1.0 & 1.0 & 1.0 & 1.0 & 1.0 & 1.0 & 1.0 & 1.0 & 1.0 & 1.0 \\
\hline NASE 14 TC & 1.0 & 1.0 & 1.0 & 1.0 & 1.0 & 1.0 & 1.0 & 1.0 & 1.0 & 1.0 & 1.0 & 1.0 \\
\hline Mean & 1.1 & 1.1 & 1.2 & 1.0 & 1.1 & 1.1 & 1.0 & 1.0 & 1.1 & 1.0 & 1.0 & 1.0 \\
\hline $\operatorname{LSD}(0.05)$ & 0.06 & 0.08 & 0.12 & 0.06 & 0.08 & 0.12 & 0.06 & 0.08 & 0.12 & 0.06 & 0.08 & 0.12 \\
\hline $\mathrm{CV}(\%)$ & 14.2 & 19.2 & 27.2 & 14.2 & 19.2 & 27.2 & 14.2 & 19.2 & 27.2 & 14.2 & 19.2 & 27.2 \\
\hline
\end{tabular}

$\mathrm{MAP}=$ months after planting, $\mathrm{TC}=$ tissue culture-derived material, $\mathrm{FS}=$ field-sourced panting material 
TABLE 5. Cassava brown streak disease root severity and incidence $(\%)$ for tissue culture and field sourced planting materials per isolation distance at 12 months after planting at the Makerere University Agriculture Research Institute, Kabanyolo (MUARIK) in Uganda

\begin{tabular}{|c|c|c|c|c|c|c|c|c|}
\hline \multirow[t]{3}{*}{ Planting materials } & \multicolumn{8}{|c|}{ Isolation distance $(\mathrm{m})$} \\
\hline & \multicolumn{2}{|c|}{50} & \multicolumn{2}{|c|}{100} & \multicolumn{2}{|c|}{150} & \multicolumn{2}{|c|}{250} \\
\hline & Rs & $\mathrm{Ri}$ & Rs & $\mathrm{Ri}$ & Rs & $\mathrm{Ri}$ & Rs & $\mathrm{Ri}$ \\
\hline NAROCASS 1 FS & 1.17 & 1.11 & 1.0 & 0 & 1.0 & 0 & 1.0 & 0 \\
\hline NAROCASS 1 TC & 1.0 & 0 & 1.0 & 0 & 1.0 & 0 & 1.0 & 0 \\
\hline NASE 03 FS & 2.5 & 41.13 & 2.25 & 28.7 & 1.58 & 9.09 & 1.0 & 0 \\
\hline NASE03 TC & 2.08 & 38.24 & 1.5 & 11.16 & 1.0 & 0 & 1.0 & 0 \\
\hline NASE 14FS & 1.67 & 17.26 & 1.33 & 4.17 & 1.0 & 0 & 1.0 & 0 \\
\hline NASE $14 \mathrm{TC}$ & 1.33 & 9.09 & 1.25 & 2.3 & 1.0 & 0 & 1.0 & 0 \\
\hline Mean & 1.6 & 17.8 & 1.4 & 7.7 & 1.1 & 1.5 & 1.0 & 0 \\
\hline $\operatorname{LSD}(0.05)$ & 0.19 & 4.75 & 0.19 & 4.75 & 0.19 & 4.75 & 0.19 & 4.75 \\
\hline $\mathrm{CV}(\%)$ & 36.6 & 174.9 & 36.6 & 174.9 & 36.6 & 174.9 & 36.6 & 174.9 \\
\hline
\end{tabular}

$\mathrm{LSD}=$ the least significant difference at $\mathrm{P}=0.05, \mathrm{CV}=$ the coefficient of variation, $\mathrm{Rs}=$ root severity, $\mathrm{Ri}$ $=$ root incidence $(\%), \mathrm{TC}=$ tissue culture-derived material, $\mathrm{FS}=$ field-sourced panting material

(tissue culture versus field sourced) to CBSV and CMV infection. Results also revealed differential prevalence of CBSD and CMD for the different cultivars (Tables 1, 2, 3, 4 and 5), an observation consistent with earlier findings (Alicai et al., 2007; Kawuki et al., 2017; Mukiibi et al., 2019).

Both FS and TC planting materials of NASE 14 and NAROCASS 1 cassava cultivars had CMD severity of 1.0 and CMD incidence of $0 \%$ (Tables 2 and 4). These findings are in agreement with observations by Mukiibi et al. (2019), who also observed no CMD symptoms on these cassava cultivars. Absence of CMD symptoms on these cassava cultivars demonstrates high levels of resistance or tolerance to the disease (Kawuki et al., 2016). These cultivars, however, succumbed to CBSD (although with less prevalence compared to NASE 03). These observations indicate a big gap that still exists for combined resistance for the two diseases. Plants from TC and FS cassava planting materials of NASE 03 had very high incidence (Tables 1,2 and 5) and severity (Tables 3, 4 and 5) for both CBSD and CMD confirming that this cultivar is most susceptible to the two diseases (Kawuki et al., 2017).

CBSD and CMD prevalence was generally higher among FS than TC planting materials (Tables 1, 2, 3, 4 and 5). This confirms the superiority of using tissue culture derived clean planting materials in the management of viral diseases in cassava compared to field sourced planting materials (Legg et al., 2011; Legg et al., 2015; Legg et al., 2017; Tumwegamire et al., 2018). These results provide an indication that phytosanitary measures, such as those involving the use of virus-free planting material, preferably TC derived, coupled with isolation from surrounding potential sources of infection, offer excellent potential for CBSD and CMD control (Maruthi et al., 2017).

The less prevalence of CBSD and CMD in plants from TC planting material is probably because through tissue culture, challenges 
such as diseases often associated with conventional practices can be overcome. Consequently, Nakabonge et al. (2017) suggested tissue culture as an important technology in setting up cassava seed systems; although many farmers in Uganda still use FS planting materials. Cyclic-propagation of FS planting materials in cassava leads to continued virus presence and build up in the environment (Maruthi et al., 2005).

CBSD was generally more prevalent than CMD (Tables 1, 2, 3 and 4). This is probably because, the cultivars used in this study were more susceptible to CBSD than CMD (Kawuki et al., 2016). CBSD and CMD prevalence was lowest in planting materials of recently released cassava cultivars NAROCASS 1 (released in 2015) and NASE 14 (released in 2011); while highest in NASE 03 (released in 1993). This shows virus evolution and progress done by the breeding program.

CBSD and CMD severity and incidence for plants from TC and FS planting materials decreased with increase in isolation distances; the $50 \mathrm{~m}$ isolation distance had the highest prevalence and $250 \mathrm{~m}$ had the lowest prevalence (Tables 6 and 7). Maruthi et al. (2017) also reported a greater CBSD incidence in plots that were closer to CBSD spreader plants. However, our results were in contrast to earlier suggestion by Maruthi et al. (2017), who reported that an isolation distance of 100 $\mathrm{m}$ is sufficient to significantly minimise the spread of CBSVs between infected and disease-free plots. Short distances favour whitefly semi persistent transmission mechanism for CBSVs (Delimini, 2012; Maruthi et al., 2017). Short isolation distance combined with high whitefly population in our study area (Abaca et al., 2012; Kaweesi et al., 2014), probably explain the high CBSD prevalence observed at the 50 and $100 \mathrm{~m}$ isolation distances. The $250 \mathrm{~m}$ isolation distance could have limited a big number of CBSV- and CMV-carrying whiteflies from reaching the healthy plants, thus the observed no CBSD and CMD prevalence at $250 \mathrm{~m}$ isolation distance although the study was set

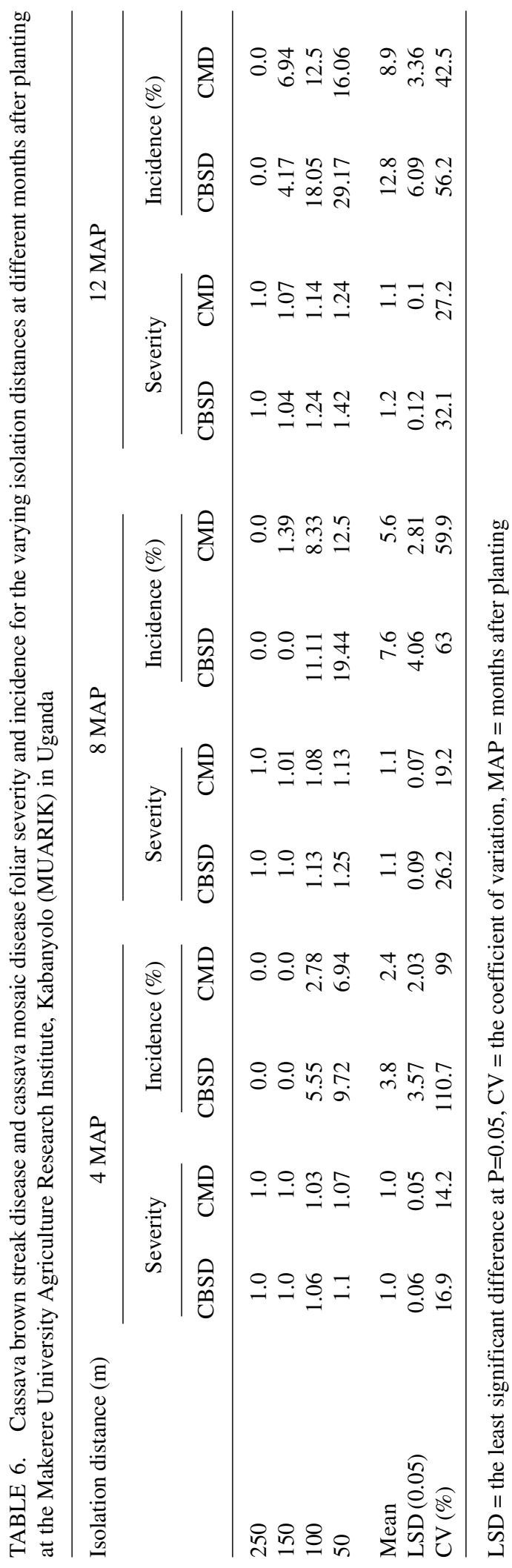


TABLE 7. Cassava brown streak disease root severity and incidence (\%) for the varying isolation distances at 12 months after planting at the Makerere University Agriculture Research Institute, Kabanyolo (MUARIK) in Uganda

\begin{tabular}{lcc}
\hline Isolation distance $(\mathrm{m})$ & CBSD root severity & CBSD root incidence $(\%)$ \\
\hline 250 & 1.0 & 0.0 \\
150 & 1.1 & 1.52 \\
100 & 1.4 & 7.7 \\
50 & 1.6 & 17.8 \\
& & \\
Mean & 1.3 & 6.8 \\
LSD $(0.05)$ & 0.15 & 3.88 \\
CV $(\%)$ & 36.6 & 174.9 \\
\hline
\end{tabular}

$\mathrm{LSD}=$ the least significant difference at $\mathrm{P}=0.05, \mathrm{CV}=$ the coefficient of variation

up in an area that is a hotspot for CBSD and CMD and with a high whitefly infestation (Abaca et al., 2012; Kaweesi et al., 2014). Our findings, therefore, can be applied both in low and high disease pressure zones to effectively manage CBSD and CMD.

\section{CONCLUSION}

This study has revealed that $250 \mathrm{~m}$ isolation distance can be instrumental in significantly preventing CBSV and CMV infections in cassava plants from tissue culture and field sourced cassava planting materials in Uganda. This distance can prevent CBSV and CMV infections in both cultivars that are susceptible and tolerant as seen by the cultivars used in this study. This provides hope for enhanced CBSD and CMD management in farmer preferred yet susceptible cultivars. Therefore, cassava seed multipliers and inspectors in Uganda can adopt this isolation distance for the production and dissemination of clean planting material. To effectively utilise findings for our study, we recommend strict regulations by inspectors to only allow cassava seed multiplication by multipliers with enough land for the $250 \mathrm{~m}$ isolation distance especially for the high disease pressure zones in Uganda.

\section{ACKNOWLEDGEMENT}

The authors are grateful to the Mastercard Foundation and Regional Universities Forum for Capacity Building in Agriculture (RUFORUM) for funding research and publication cost through the Transforming African Agricultural Universities to meaningfully contribute to Africa's growth and development (TAGDev) Program. The contribution of National Cassava Program of the National Crops Resources Research Institute - Namulonge and Makerere University Agricultural Research Institute - Tissue Culture Laboratory, are highly appreciated.

\section{REFERENCES}

Abaca, A., Kawuki, R., Tukamuhabwa, P., Baguma, Y., Pariyo, A., Alicai, T., Omongo, C.A. and Bua, A. 2012. Progression of cassava brown streak disease (CBSD) in infected cassava roots in Uganda. Uganda Journal of Agricultural Sciences 13:45-51.

Alicai, T., Omongo, C.A., Maruthi, M.N., Hillocks, R.J., Baguma, Y., Kawuki, R., Bua, A., Otim-Nape, G.W. and Colvin, J. 2007. Re-emergence of cassava brown streak disease in Uganda. Plant Disease 91:24-29. 
Beyene, G., Chauhan, R.D., Ilyas, M., Wagaba, H., Fauquet, C.M., Miano, D., Alicai, T. and Taylor, N. J. 2017. A virus-derived stacked RNAi construct confers robust resistance to Cassava brown streak disease. Frontiers in Plant Science 7:2052.

Beyene, G., Chauhan, R.D., Wagaba, H., Moll, T., Alicai, T., Miano, D., Carrington, J.C. and Taylor, N.J. 2016. Loss of CMD2mediated resistance to Cassava mosaic disease in plants regenerated through somatic embryogenesis. Molecular Plant Pathology 17:1095-1110.

Delimini, L. 2012. Seed Production and Training Manual. Food and Agriculture Organization, (FAO)/Germany Cooperative Programme for Ministry of Agriculture, Forestry and Food Security, Sierra Leone.

FAOSTAT. 2017. FAO database. Food and Agriculture Organization of the United Nations, Rome, Italy.

Gondwe, F.M.T., Mahungu, N.M., Hillocks, R.J., Moyo, C.C., Soko, M.M. and Benesi, I.R.M. 2003. Economic losses experienced by small-scale farmers in Malawi due to cassava brown streak virus. In: Legg, J.P. and Hillocks, R.J. (Eds.), Cassava Brown Streak Disease: Past, present and future (pp.28-35). Proceedings of an International Workshop, Mombasa, Kenya, 20-30 October 2002. National Resources International Limited, Aylesford, UK. pp. $28-35$.

International Institute of Tropical Agriculture (IITA). 1990. Cassava in Tropical Africa: A reference manual. Ibadan, Nigeria. pp. $61-63$.

Kaweesi, T., Kawuki, R., Kyaligonza, V., Baguma, Y., Tusiime, G. and Ferguson, M.E. 2014. Field evaluation of selected cassava genotypes for cassava brown streak disease based on symptom expression and virus load. Virology Journal 11:216.

Kawuki, R.S., Kaweesi, T., Esuma, E., Pariyo, A., Kayondo, S.I., Ozimati, A. 2016. Eleven years of breeding efforts to combat cassava brown streak disease. Breeding Science Preview 66:560-571.

Kawuki, R.S., Adiga, G., Orone, J., Alicai, T., Edimu, M., Omara, T., Pariyo, A., Esuma, W., Omongo, C., Bua, A., Kanju, E. and Baguma, Y. 2017. Limits of phytosanitation and host plant resistance towards the control of cassava viruses in Uganda. African Journal of Rural Development 2:455-466.

Legg, J.P., Jeremiah, S.C., Obiero, H.M., Maruthi, M.N., Ndyetabula, I., OkaoOkuja, G., Bouwmeester, H., Bigirimana, S., Tata-Hangy, W., Gashaka, G., Mkamilo, G., Alicai., T. and Lava Kumar, P. 2011. Comparing the regional epidemiology of the cassava mosaic and cassava brown streak virus pandemics in Africa. Virus Research159:161-170.

Legg, J.P., Somado, E.A., Barker, I., Beach, L., Ceballos, H., Cuellar, W. 2014. A global alliance declaring war on cassava viruses in Africa. Food Security 6:231-248.

Legg, J.P., Lava Kumar, P., Makeshkumar, T., Tripathi, L., Ferguson, M., Kanju, E., Ntawuruhunga, P. and Cuellar, W. 2015. Cassava virus diseases: biology, epidemiology, and management. In: Loebenstein, Gad, Katis and Nikolaos, I. (Eds.), Advances in Virus Research 91:85142.

Legg, J.P.,Ndalahwa, M., Yabeja, J., Ndyetabula, I., Bouwmeester, H., Shirima, R. and Mtunda, K. 2017. Community phytosanitation to manage cassava brown streak disease. Virus Research 241:236253.

Maruthi, M.N., Colvin, J., Seal, S., Gibson, G. and Cooper, J. 2002. Co-adaptation between cassava mosaic geminiviruses and their local vector populations. Virus Research 86:71-85.

Maruthi, M.N., Hillocks, R.J., Mtunda, K., Raya, M.D., Muhanna, M., Kiozia, H. 2005. Transmission of Cassava brown streak virus by Bemisia tabaci (Gennadius). Journal of Phytopathology 153:307-312. 
Maruthi, M.N., Jeremiah, S.C., Mohammed, I.U. and Legg, J.P. 2017. The role of the whitefly, Bemisia tabaci (Gennadius), and farmer practices in the spread of cassava brown streak ipomo viruses. Journal of Phytopathology 165:707-717.

Ministry of Agriculture, Animal Industry and Fisheries (MAAIF). 2010. The seeds and plant regulations 2010, on recommendation of the National Seed Board (Under Section 28 of the Seeds and Plant Act, Act No. 3 of 2006).

Mukiibi, D.R., Alicai. T., Kawuki, R., OkaoOkuja, G., Tairo, F., Sseruwagi, P., Ndunguru, J. and Ateka, E.M. 2019. Resistance of advanced cassava breeding clones to infection by major viruses in Uganda. Crop Protection 115:104-112.

Nakabonge, G., Samukoya, C. and Baguma, Y. 2017. Local varieties of cassava: Conservation, cultivation and use in Uganda. Environment, Development and
Sustainability. doi: 10.1007/s10668-0179997-6.

Payne, R.W., Harding, S.A., Murray, D.A., Soutar, D.M., Baird, D.B., Glaser, A.I., Welham, S.J., Gilmour, A.R., Thompson, R. and Webster, R. 2011. The Guide to Genstat Release 14, Part 2: Statistics. VSN International, Hemel Hempstead.

Tumwegamire, S., Kanju, E., Legg, J.P, Shirima, R., Kombo, S.,Mkamilo, G., Mtunda, K., Sichalwe, K., Kulembeka, H., Ndyetabura, I., Saleh, H., Kawuki, R. and Alicai, T. 2018. Exchanging and managing in-vitro elite germplasm to combat Cassava Brown Streak Disease (CBSD) and Cassava Mosaic Disease (CMD) in Eastern and Southern Africa. Food Security 10:351-368.

UBOS. 2017. Uganda Bureau of Statistics 2017 Statistical Abstract. Ministry of Finance, Planning and Economic Development, Government of Uganda. 